\title{
Further Observations on Carbohydrate Metabolism and its Regulation in Azotobacter beijerinckii
}

\author{
By MICHAEL P. STEPHENSON,* FRANK A. JACKSON $\dagger$ \\ AND EDWIN A. DAWES \\ Department of Biochemistry, University of Hull, Hull HU6 7RX
}

(Received 31 May 1978)

\begin{abstract}
Certain enzymes of glucose catabolism in Azotobacter beijerinckii were studied and their activities in steady-state chemostat cultures were measured under various nutrient limitations. 2-Keto-3-deoxy-6-phosphogluconate aldolase was separated from 6-phosphogluconate dehydratase by affinity chromatography and the previously observed inhibition of the Entner-Doudoroff enzymes by tricarboxylic acids and ATP was attributed to chelation of $\mathrm{Mn}^{2+}$ and $\mathrm{Mg}^{2+}$ which activate the dehydratase. Glucose-6-phosphate dehydrogenase was unaffected by phosphoenolpyruvate while fructose-1,6-bisphosphate aldolase was activated by $\mathrm{Co}^{2+}, \mathrm{K}^{+}$or $\mathrm{NH}_{4}{ }^{+}$ions. Transketolase, transaldolase and triosephosphate isomerase were present but previous reports of 6-phosphogluconate dehydrogenase activity were shown to be artefacts. The findings confirm the major role of the Entner-Doudoroff pathway in glucose catabolism in $A$. beijerinckii. Pyruvate dehydrogenase, a key enzyme for carbon entry to the tricarboxylic acid cycle and to poly- $\beta$-hydroxybutyrate synthesis, was inhibited by acetyl-coenzyme A and NADH.
\end{abstract}

\section{INTRODUCTION}

Glucose is metabolized in Azotobacter vinelandii principally via the Entner-Doudoroff pathway as indicated by enzymic (Mortenson \& Wilson, 1954; Mortenson et al., 1955; Haaker \& Veeger, 1976) and radiorespirometric studies (Still \& Wang, 1964), and the same is true of Azotobacter beijerinckii (Senior \& Dawes, 1971). Previously we have examined various aspects of the regulation of carbohydrate metabolism of $A$. beijerinckii in relation to poly- $\beta$-hydroxybutyrate biosynthesis (Senior \& Dawes, 1971). Subsequently it became necessary to amplify some of this earlier work done with batch-grown organisms and the opportunity was taken to use the controlled conditions of the chemostat to make comparisons of oxygen- and carbon-limited bacteria for some of the enzymes. Attention was also directed to the role of the oxidative pentose phosphate pathway, entry to which is gained via 6-phosphogluconate dehydrogenase, since spurious assays for the latter enzyme can occur in the presence of an active Entner-Doudoroff system and an NADP-dependent glyceraldehyde-3-phosphate dehydrogenase, as noted for Pseudomonas aeruginosa by Blevins et al. (1975). As our previous investigations of the control of glucose metabolism and the tricarboxylic acid cycle in $A$. beijerinckii did not embrace pyruvate dehydrogenase, we have included it in the present survey which was designed to supplement the earlier work of Senior \& Dawes (1971).

* Present address: Forensic Science Laboratory, Shakespeare Street, Nottingham NG1 4FR.

$\dagger$ Present address: Cyanamid of Great Britain Ltd, Fareham Road, Gosport, Hants PO13 0AS. 


\section{METHODS}

Organism. The organism was a capsuleless mutant of Azotobacter beijerinckii NCIB 9067, isolated by Senior et al. (1972), and now lodged as NCrB 11292.

Growth of the organism. Details of the chemostat, maintenance of the organism, growth media, growth of the organism for inocula, growth conditions, bacterial dry weight measurement, and control and determination of dissolved oxygen tension in the culture have been described previously (Senior et al., 1972). The oxygen electrode (L. H. Engineering Co., Bells Hill, Stoke Poges, Bucks.) was sterilized in situ by autoclaving with the culture vessel. For oxygen-limited steady states (undetectable dissolved oxygen tension), the flow rates of oxygen and nitrogen were adjusted manually to the required values using the Flostat valves and rotameters. Nitrogen-limited steady states were established using argon as an inert carrier gas (flow rate 1 litre $\mathrm{min}^{-1}$ ) to which the required amount of nitrogen was added by manual adjustment of the nitrogen Flostat valve; oxygen flow rate was adjusted automatically by the controller. For carbon-limited conditions, the nitrogen flow rate $\left(1\right.$ litre $\left.\min ^{-1}\right)$ was adjusted manually and the oxygen flow rate was adjusted automatically by the controller.

Enzyme assays. Bacterial extracts were prepared by the methods of Senior \& Dawes (1973) and, according to assay, were diluted to contain 50 to $750 \mu \mathrm{g}$ protein $\mathrm{ml}^{-1}$. All enzyme assays were performed at $30^{\circ} \mathrm{C}$ under previously determined optimum conditions, except for transketolase, where shortage of substrate prevented establishment of the optimum. A Pye Unicam SP1800 recording spectrophotometer was used for all spectrophotometric assays.

6-Phosphogluconate dehydratase (EC 4.2.1.12) and 2-keto-3-deoxy-6-phosphogluconate (KDPG) aldolase (EC 4.1.2.14). A combined assay for these enzymes measured pyruvate production from 6-phosphogluconate using lactate dehydrogenase and NADH. Silica glass cuvettes $(1 \mathrm{~cm}$ light path) contained $(\mathrm{ml})$ : $\mathrm{MnCl}_{2}(80 \mathrm{~mm}), 0 \cdot 01$; dithiothreitol $(80 \mathrm{mM}), 0 \cdot 2$; lactate dehydrogenase $\left(1 \mathrm{mg} \mathrm{ml}^{-1}, 200\right.$ to 400 i.u. $\left.\mathrm{mg}^{-1}\right)$, 0.01 ; NADH (10 mM), 0.2; bacterial extract, 0.05 to $0 \cdot 2$; 6-phosphogluconate $(50 \mathrm{~mm}), 0 \cdot 2$; triethanolamine $/ \mathrm{HCl}$ buffer $(100 \mathrm{mM}, \mathrm{pH} 7 \cdot 7)$ to $3.2 \mathrm{ml}$. The rate of any endogenous $\mathrm{NADH}$ oxidation was measured at $340 \mathrm{~nm}$ before initiating the reaction by adding 6-phosphogluconate.

6-Phosphogluconate dehydratase was measured as for the combined assay but sufficient partially purified KDPG aldolase from $A$. beijerinckii was added to ensure that the rate-limiting step was the conversion of 6-phosphogluconate to KDPG.

$K D P G$ aldolase was assayed by measuring pyruvate formation from KDPG. Cuvettes contained $(\mathrm{ml})$ : NADH (10 mM), 0.2; lactate dehydrogenase $\left(1 \mathrm{mg} \mathrm{ml}^{-1}, 200\right.$ to $\left.400 \mathrm{i} . \mathrm{u} . \mathrm{mg}^{-1}\right), 0.01$; bacterial extract, 0.05 to $0 \cdot 2$; KDPG $(30 \mathrm{~mm}), 0 \cdot 3$; triethanolamine $/ \mathrm{HCl}$ buffer $(100 \mathrm{mM}, \mathrm{pH} 7 \cdot 7)$ to $3.2 \mathrm{ml}$, and the assay was conducted as for the combined enzymes.

6-Phosphogluconate dehydrogenase (EC 1.1.1.44). The reduction of NADP was measured at $340 \mathrm{~nm}$ with cuvettes containing $(\mathrm{ml}): \mathrm{MgCl}_{2}(50 \mathrm{mM}), 0 \cdot 1$; NADP $(5 \mathrm{~mm}), 0 \cdot 2 ; 6$-phosphogluconate $(50 \mathrm{~mm}), 0 \cdot 2$; bacterial extract $\left(50\right.$ to $750 \mu \mathrm{g}$ protein $\left.\mathrm{ml}^{-1}\right), 0.05$ to 0.1 ; hydrazine $(0.96 \mathrm{M}), 0.2$; triethanolamine $/ \mathrm{HCl}$ buffer $(100 \mathrm{~mm}, \mathrm{pH} 7 \cdot 7)$ to $3.2 \mathrm{ml}$.

A radiochemical assay was also used. The main compartment of Warburg flasks contained (ml): sodium [1.-14 C]gluconate (25 mM, $\left.0 \cdot 1 \mathrm{mCi} \mathrm{mmol}^{-1}\right), 0 \cdot 5$; Tris/HCl buffer $(0 \cdot 12 \mathrm{M}, \mathrm{pH} 7 \cdot 5), 0 \cdot 9 ;$ ATP (36 mM), 0.1; gluconate kinase ( 40 units $\mathrm{ml}^{-1}$ ), 0.02 ; water, 0.08 . The side-arm contained $0.5 \mathrm{ml}$ bacterial extract and the centre well contained $0.05 \mathrm{ml}$ Hyamine hydroxide and a roll of Whatman no. 541 filter paper. The system was incubated at $30^{\circ} \mathrm{C}$ for $1 \mathrm{~h}$ to allow phosphorylation of the gluconate before the side-arm contents were tipped. After a predetermined time, the reaction was terminated by the addition of $2 \mathrm{M}^{-} \mathrm{H}_{2} \mathrm{SO}_{4}(0.5 \mathrm{ml})$ and the incubation was continued for $1 \mathrm{~h}$ to allow absorption of the $\mathrm{CO}_{2}$ by the Hyamine hydroxide. The contents of the centre wells were quantitatively transferred with methanol to volumetric flasks and the radioactivity was determined by scintillation counting of samples in Bray's (1960) fluid. Corrections were made for non-enzymic ${ }^{14} \mathrm{CO}_{2}$ release recorded with boiled extract controls.

Glucose-6-phosphate dehydrogenase (EC 1.1.1.49). The reduction of NADP was measured at $340 \mathrm{~nm}$ with cuvettes containing $(\mathrm{ml})$ : NADP $(5 \mathrm{~mm}), 0 \cdot 3$; bacterial extract, $0 \cdot 1$; glucose 6 -phosphate $(30 \mathrm{~mm})$, 0.5 ; imidazole $/ \mathrm{HCl}$ buffer $(100 \mathrm{~mm}, \mathrm{pH} 7.5)$ to $3.0 \mathrm{ml}$. The reaction was initiated by addition of the substrate.

Phosphoglucose isomerase (EC 5.3.1.9). The rate of formation of glucose 6-phosphate from fructose 6-phosphate was measured spectrophotometrically by coupling to glucose-6-phosphate dehydrogenase. Cuvettes contained $(\mathrm{ml}): \mathrm{MgCl}_{2}(100 \mathrm{~mm}), 0 \cdot 2$; NADP $(10 \mathrm{~mm}), 0 \cdot 2$; fructose 6-phosphate (100 mM), 0.3; glucose-6-phosphate dehydrogenase (300 to 400 i.u. $\mathrm{mg}^{-1}, 1 \mathrm{mg} \mathrm{ml}^{-1}$ ), 0.01 ; bacterial extract, 0.05 ; triethanolamine $/ \mathrm{HCl}$ buffer $(100 \mathrm{mM}, \mathrm{pH} 7 \cdot 9$, containing $0.1 \mathrm{M}$-hydrazine) to $3.16 \mathrm{ml}$. The substrate was checked for contamination with glucose 6-phosphate before initiating the reaction with the extract.

Fructose-1,6-bisphosphate aldolase (EC 4.1.2.13). The rate of formation of dihydroxyacetone phosphate 
from fructose 1,6-bisphosphate directly, and indirectly via glyceraldehyde 3-phosphate and triosephosphate isomerase, was assayed spectrophotometrically by coupling to glycerol-1-phosphate dehydrogenase. Cuvettes contained $(\mathrm{ml})$ : NADH $(10 \mathrm{~mm}), 0 \cdot 2 ; \mathrm{CoSO}_{4}(30 \mathrm{~mm}), 0 \cdot 1 ;$ glycerol-1-phosphate dehydrogenase (GDH)/ triosephosphate isomerase (TPI) mixture (GDH, 100 to 200 i.u. $\mathrm{mg}^{-1}, 1 \mathrm{mg} \mathrm{ml}^{-1}$; TPI, 1000 to 2000 i.u. $\left.\mathrm{mg}^{-1}, 1 \mathrm{mg} \mathrm{ml} \mathrm{l}^{-1}\right), 0 \cdot 01$; bacterial extract, $0 \cdot 1$; fructose 1,6 -bisphosphate $(30 \mathrm{~mm}), 0 \cdot 1$; triethanolamine $/ \mathrm{HCl}$ $(100 \mathrm{~mm}, \mathrm{pH} 7 \cdot 7)$ to $3.0 \mathrm{ml}$. All reagents except the substrate were incubated for $3 \mathrm{~min}$ before initiating the reaction.

Phosphofructokinase (EC 2.7.1.11). The enzyme was assayed by converting the reaction product, fructose 1,6-bisphosphate, to glycerol 1-phosphate in the presence of aldolase, triosephosphate isomerase and glycerol-1-phosphate dehydrogenase and measuring the concomitant oxidation of NADH. Cuvettes contained $(\mathrm{ml})$ : fructose 6-phosphate (40 mM), 0.05; NADH (10 mM), 0.05; ATP (20 mM), 0.01; $\mathrm{MgCl}_{2}\left(10 \mathrm{~mm}^{2}\right.$, 0.1 ; fructose-1,6-bisphosphate aldolase $\left(9\right.$ units $\left.\mathrm{mg}^{-1}, 10 \mathrm{mg} \mathrm{ml}^{-1}\right), 0.01$; triosephosphate isomerase $(2400$ units $\mathrm{mg}^{-1}, 2 \mathrm{mg} \mathrm{ml}^{-1}$ ), $0 \cdot 01$; glycerol-1-phosphate dehydrogenase (36 units $\mathrm{mg}^{-1}, 2 \mathrm{mg} \mathrm{ml}^{-1}$ ), $0 \cdot 01$; bacterial extract ( 5 to $10 \mathrm{mg}$ protein $\mathrm{ml}^{-1}$ ), $0 \cdot 01$; triethanolamine/ $\mathrm{HCl}$ buffer $(100 \mathrm{mM}, \mathrm{pH} 7 \cdot 6)$ to $3 \cdot 0 \mathrm{ml}$. The reaction was initiated with ATP.

Triosephosphate isomerase (EC 5.3.1.1). The production of dihydroxyacetone phosphate from glyceraldehyde 3-phosphate was measured spectrophotometrically by coupling to glycerol-1-phosphate dehydrogenase. Cuvettes contained $(\mathrm{ml})$ : NADH $(10 \mathrm{~mm}), 0 \cdot 2$; glycerol-1-phosphate dehydrogenase $\left(200 \mathrm{i} . \mathrm{u} . \mathrm{mg}^{-1}\right.$, $\left.1 \mathrm{mg} \mathrm{ml}^{-1}\right), 0.01$; bacterial extract, $0 \cdot 01$ to 0.04 ; glyceraldehyde 3 -phosphate $(5 \mathrm{~mm}), 0 \cdot 7$; triethanolamine/ $\mathrm{HCl}$ buffer $(100 \mathrm{mM}, \mathrm{pH} 7 \cdot 7)$ to $3.0 \mathrm{ml}$. The reaction was initiated by the addition of substrate.

Transaldolase (EC 2.2.1.2). Activity was assayed spectrophotometrically by measuring the rate of glyceraldehyde 3-phosphate production from fructose 6-phosphate and erythrose 4-phosphate in a coupled reaction using glycerol-1-phosphate dehydrogenase and triosephosphate isomerase with NADH. Cuvettes contained (ml): EDTA (0.1 M, pH 7.7), 0.1; fructose 6-phosphate (100 mM), 0.05; NADH (10 mM), 0.07; GDH/TPI mixture (GDH, 100 to 200 i.u. $\mathrm{mg}^{-1}, 1 \mathrm{mg} \mathrm{ml}{ }^{-1}$; TPI, 1000 to 2000 i.u. $\mathrm{mg}^{-1}, 1 \mathrm{mg} \mathrm{ml}^{-1}$ ), 0.01; bacterial extract, $0 \cdot 04$; erythrose 4-phosphate $(10 \mathrm{~mm}) 0 \cdot 2$; triethanolamine/HCl buffer $(200 \mathrm{~mm}, \mathrm{pH} \mathrm{7.7)}$ to $1.3 \mathrm{ml}$. The endogenous rate of $\mathrm{NADH}$ oxidation was ascertained prior to initiating the reaction by addition of erythrose 4-phosphate.

Transketolase (EC 2.2.1.1). Activity was determined spectrophotometrically by measuring the rate of glyceraldehyde 3-phosphate production from ribose 5-phosphate and xylulose 5-phosphate in a coupled reaction with glycerol-1-phosphate dehydrogenase, triosephosphate isomerase and NADH. Cuvettes contained $(\mathrm{ml}): \mathrm{MgCl}_{2}(0 \cdot 1 \mathrm{M}), 0 \cdot 1$; NADH $(10 \mathrm{mM}), 0.07$; GDH/TPI mixture (as above), 0.01 ; thiamin pyrophosphate $(20 \mathrm{mM}), 0.03$; ribose 5 -phosphate $(50 \mathrm{mM}), 0 \cdot 1$; xylulose 5 -phosphate $(10 \mathrm{~mm}), 0 \cdot 1$; bacterial extract, $0 \cdot 1$; triethanolamine $/ \mathrm{HCl}$ buffer $(200 \mathrm{mM}, \mathrm{pH} 7 \cdot 7)$ to $1.3 \mathrm{ml}$. The reaction was initiated by addition of the extract and the endogenous rate of NADH oxidation was measured by omitting the substrates.

Pyruvate dehydrogenase (EC 1.2.4.1). The enzyme was assayed spectrophotometrically by the method of Jackson \& Dawes (1976).

Preparation of KDPG. A mutant of Escherichia coli $\mathrm{K} 12$ (designated DF 1071-2B), lacking KDPG aldolase and isolated by Faik et al. (1971), was kindly provided by Professor Sir Hans Kornberg. An extract of this organism was used to convert 6-phosphogluconate to KDPG essentially as described by Faik et al. (1971) although the quantities were scaled up. The product was purified by the method of Meloche \& Wood (1966).

Preparation of $\omega$-aminoalkyl Sepharose. The method of Shaltiel \& Er-Al (1973) was employed to prepare, from Sepharose $4 \mathrm{~B}$, derivatives of the type Sepharose-NH( $\left(\mathrm{CH}_{2}\right)_{n} \mathrm{NH}_{2}$ where $n=2,3,4,5,6$ or 8 (subsequently designated $\mathrm{C}_{2}, \mathrm{C}_{3}$ etc.).

Enzyme purification. The separation and purification of 6-phosphogluconate dehydratase and KDPG aldolase was attempted with various $\omega$-aminoalkyl Sepharoses. Trials were conducted by applying crude extract $\left(0.5 \mathrm{ml}\right.$, about $4 \mathrm{mg}$ protein) to small columns $(0.5 \times 4 \mathrm{~cm})$ of the gels equilibrated at $4{ }^{\circ} \mathrm{C}$ with triethanolamine/ $\mathrm{HCl}$ buffer $(100 \mathrm{~mm}, \mathrm{pH} 7 \cdot 7)$, containing $1 \mathrm{~mm}$-dithiothreitol. KDPG aldolase was detected in eluates from $\mathrm{C}_{2}, \mathrm{C}_{3}$ or $\mathrm{C}_{4}$ columns but not in those from $\mathrm{C}_{5}, \mathrm{C}_{6}$ or $\mathrm{C}_{8}$. A larger scale preparation was then undertaken with $C_{5}$ gel. Extract $(2.5 \mathrm{ml}, 20 \mathrm{mg}$ protein) was applied to a column $(1 \times 5 \mathrm{~cm})$ in a disposable $5 \mathrm{ml}$-syringe and the column was washed with $50 \mathrm{ml}$ of the buffer. The molarity of the eluting buffer was increased to $150 \mathrm{~mm}$ (containing $1 \mathrm{~mm}$-dithiothreitol) and $3 \mathrm{ml}$ fractions were collected and monitored for KDPG aldolase. Activity was located in fractions 5 to 12 with the maximum in fractions 8 to 10; these latter fractions were pooled. This method resulted in a 10 -fold purification of the aldolase.

Using a similar technique, the behaviour of 6-phosphogluconate dehydratase was studied. Eluates were supplemented with partially purified KDPG aldolase and monitored for activity, which was found in fractions from $C_{2}$ to $C_{4}$ columns but not from $C_{5}$ to $C_{8} . A C_{5}$ column was thus used, crude extract was applied and all unbound protein was eluted with $100 \mathrm{~mm}$-triethanolamine $/ \mathrm{HCl}(\mathrm{pH} 7 \cdot 7)$. The molarity 
of the eluting buffer was increased stepwise to $150,200,300$ and finally $600 \mathrm{~mm}$ but dehydratase activity was not detected in any fraction collected. A similar result was obtained when the eluting buffer contained $10 \mathrm{~mm}$-dithiothreitol.

Glucose-6-phosphate dehydrogenase was purified 36-fold by the use of $\mathrm{C}_{5}$-Sepharose $4 \mathrm{~B}$ gel which had been equilibrated with $20 \mathrm{~mm}$-potassium phosphate buffer, pH $7 \cdot 5$. The bound enzyme was eluted with 100 mm-potassium phosphate.

Pyruvate dehydrogenase was partially purified from oxygen-limited organisms grown at a dilution rate of $0 \cdot 1 \mathrm{~h}^{-1}$. Crude bacterial extract $\left(20 \mathrm{ml}, 7 \cdot 4 \mathrm{mg}\right.$ protein $\left.\mathrm{ml}^{-1}\right)$ was centrifuged at $100000 \mathrm{~g}$ for $1 \mathrm{~h}$ and $2 \mathrm{ml} 1 \%(\mathrm{w} / \mathrm{v})$ protamine sulphate was added to the supernatant. The resulting precipitate was sedimented at $12000 \mathrm{~g}$ for $10 \mathrm{~min}$ and to $18 \mathrm{ml}$ of the supernatant was added $4.32 \mathrm{~g}\left(\mathrm{NH}_{4}\right)_{2} \mathrm{SO}_{4}$ to give $40 \%$ saturation. The precipitate was collected by centrifuging at $12000 \mathrm{~g}$ for $10 \mathrm{~min}$, resuspended in $5 \mathrm{ml} 0.05 \mathrm{M}$-potassium phosphate buffer ( $\mathrm{pH} \mathrm{7.0)} \mathrm{containing} 1 \mathrm{~mm}$-mercaptoethanol, and applied to a column of $5 \mathrm{ml}$ Sepharose 2B. The column was eluted with similar buffer and fractions between 105 and $180 \mathrm{ml}$ displayed pyruvate dehydrogenase activity. A 44-fold purification was achieved.

Analyses. Protein, acetyl-CoA and glucose were determined by the methods previously described (Senior \& Dawes, 1973; Senior et al., 1972).

Chemicals and biochemicals. Chemicals were of analytical reagent grade where possible and were obtained from BDH or Hopkin \& Williams. Biochemicals were obtained from Sigma or Boehringer. Diamines for the preparation of substituted Sepharose came from $B D H$, with the exception of the $C_{4}$ and $C_{8}$ amines which were obtained from Ralph N. Emanuel, Wembley (now the Aldrich Chemical Co., Gillingham, Dorset).

\section{RESULTS}

Entner-Doudoroff enzymes. The overall activity of the combined enzymes of this pathway (6-phosphogluconate dehydratase and KDPG aldolase) displayed an optimum $\mathrm{pH}$ of $7 \cdot 9$ and dependence on a thiol compound. The optimum concentration of dithiothreitol was $10 \mathrm{~mm}$ and, at equivalent thiol concentration, glutathione was equally effective. Crude extracts could be held at $0{ }^{\circ} \mathrm{C}$ for $48 \mathrm{~h}$ without loss of activity if thiol compounds were added. Activity was stimulated by $\mathrm{Mn}^{2+}$ but above $0.25 \mathrm{~mm}$ inhibition occurred and at $5 \mathrm{~mm}$ the rate had decreased by about $25 \% ; \mathrm{Mg}^{2+}$ at $0.25 \mathrm{~mm}$ was only about $70 \%$ as effective as $\mathrm{Mn}^{2+}$.

KDPG aldolase was separated from 6-phosphogluconate dehydratase by affinity chromatography on modified Sepharose 4B but all attempts to elute the active dehydratase failed. KDPG aldolase, purified 10 -fold by this method, gave optimum activity in triethanolamine $/ \mathrm{HCl}$ buffer at $\mathrm{pH} 8.4$ and was unaffected by $\mathrm{Mn}^{2+}, \mathrm{Mg}^{2+}$ or thiol compounds, indicating that 6-phosphogluconate dehydratase was the locus of the effects of these agents observed in the combined assay. The enzyme was stable in $150 \mathrm{~mm}$-triethanolamine $/ \mathrm{HCl}$ buffer, pH 7.7, at $4{ }^{\circ} \mathrm{C}$ for $7 \mathrm{~d}$ without loss of activity. No inhibition was observed in the presence of ATP, citrate, isocitrate or cis-aconitate at concentrations of up to $5 \mathrm{~mm}$.

Because attempts to separate and purify 6-phosphogluconate dehydratase were unsuccessful, inhibition studies were performed with crude extracts supplemented with partially purified KDPG aldolase to ensure that the rate-limiting step was the production of KDPG from 6-phosphogluconate. ATP (5 mM) caused $25 \%$ inhibition both in the absence and presence of $0.5 \mathrm{~mm}-\mathrm{Mn}^{2+}$. In contrast, in the presence of $5 \mathrm{~mm}-\mathrm{Mn}^{2+}$, ATP up to $5 \mathrm{~mm}$ relieved the inhibition produced by $\mathrm{Mn}^{2+}$. This latter effect was attributed to ATP decreasing the effective concentration of $\mathrm{Mn}^{2+}$, by chelation, towards the optimum of $0.25 \mathrm{~mm}$. Citrate ( $5 \mathrm{~mm}$ ) produced about $70 \%$ inhibition in the absence of added metal ions but had

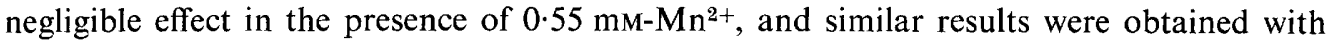
isocitrate and cis-aconitate. These findings suggest that the inhibition by tricarboxylic acids recorded by Senior \& Dawes (1971) with unsupplemented extracts could be attributed to chelation of the activating metal ion by the inhibitor. The overall activity of the combined Entner-Doudoroff enzymes did not display any marked change in response to carbon or nitrogen limitation or to dilution rate (Table 1).

Glucose-6-phosphate dehydrogenase. This enzyme is regulated allosterically by ATP, ADP, NADH and NADPH (Senior \& Dawes, 1971) and in these respects bears a marked resem- 
Table 1. Specific activities of various enzymes of glucose metabolism in steady-state chemostat cultures of $A$. beijerinckii

\begin{tabular}{|c|c|c|c|c|}
\hline Enzyme & $\begin{array}{c}\text { Specific } \\
\text { activity } \\
{\left[\text { mmol min }{ }^{-1}\right.} \\
\left.(\text { mg protein })^{-1}\right]\end{array}$ & $\begin{array}{l}\text { Limiting } \\
\text { nutrient }\end{array}$ & $\begin{array}{l}\text { Dissolved } \\
\text { oxygen } \\
\text { tension* } \\
\text { (\% air satn) }\end{array}$ & $\begin{array}{c}\text { Dilution } \\
\text { rate } \\
\left(\mathrm{h}^{-1}\right)\end{array}$ \\
\hline Glucose-6-phosphate dehydrogenase & $\begin{array}{l}2100 \\
1100\end{array}$ & $\begin{array}{l}\text { Carbon } \\
\text { Oxygen }\end{array}$ & $\begin{array}{l}5 \cdot 0 \\
\text { ND }\end{array}$ & $\begin{array}{l}0 \cdot 10 \\
0 \cdot 10\end{array}$ \\
\hline Phosphoglucose isomerase & 550 & Carbon & $5 \cdot 0$ & $0 \cdot 10$ \\
\hline Entner-Doudoroff enzymes & $\begin{array}{l}1710 \\
1690 \\
1870 \\
1610 \\
1750 \\
1870 \\
1810\end{array}$ & $\begin{array}{l}\text { Carbon } \\
\text { Carbon } \\
\text { Carbon } \\
\text { Carbon } \\
\text { Carbon } \\
\text { Nitrogen } \\
\text { Nitrogen }\end{array}$ & $\begin{array}{r}5 \cdot 0 \\
5 \cdot 0 \\
7 \cdot 5 \\
10 \cdot 0 \\
10 \cdot 0 \\
5 \cdot 0 \\
10 \cdot 0\end{array}$ & $\begin{array}{l}0 \cdot 10 \\
0 \cdot 20 \\
0 \cdot 10 \\
0 \cdot 12 \\
0 \cdot 21 \\
0 \cdot 14 \\
0 \cdot 14\end{array}$ \\
\hline Fructose-1,6-bisphosphate aldolase & $\begin{array}{l}95 \\
73 \\
76\end{array}$ & $\begin{array}{l}\text { Carbon } \\
\text { Oxygen } \\
\text { Oxygen }\end{array}$ & $\begin{array}{l}10 \cdot 0 \\
\text { ND }{ }^{\dagger} \\
\text { ND }\end{array}$ & $\begin{array}{l}0 \cdot 12 \\
0 \cdot 11 \\
0 \cdot 11\end{array}$ \\
\hline Triosephosphate isomerase & $\begin{array}{l}5000 \\
2700 \\
3100\end{array}$ & $\begin{array}{l}\text { Carbon } \\
\text { Oxygen } \\
\text { Oxygen }\end{array}$ & $\begin{array}{c}10 \cdot 0 \\
\text { ND } \dagger \\
\text { ND }\end{array}$ & $\begin{array}{l}0 \cdot 12 \\
0 \cdot 11 \\
0 \cdot 11\end{array}$ \\
\hline Transketolase & $56+$ & Carbon & $10 \cdot 0$ & $0 \cdot 12$ \\
\hline Transaldolase & 100 & Carbon & $10 \cdot 0$ & $0 \cdot 12$ \\
\hline \multicolumn{5}{|c|}{$\begin{array}{l}\text { ND, Not detected. } \\
\text { * For carbon-limited cultures the nitrogen flow rate was set at } 1 \text { litre } \min ^{-1} \text { and the oxygen flow rate was } \\
\text { djusted automatically to produce the required dissolved oxygen tension. For oxygen-limited cultures the } \\
\text { xygen content of the inflowing gas was } 1 \%(\mathrm{v} / \mathrm{v}) \text { with a total gas flow of } 1 \text { litre } \min ^{-1} \text { (except where } \\
\text { idicated). } \\
\dagger \text { Oxygen content of inflowing gas } 2 \cdot 8 \%(\mathrm{v} / \mathrm{v}) \text {; total flow rate } 1 \text { litre } \mathrm{min}^{-1} \text {. } \\
\ddagger \text { At } \mathrm{pH} 7 \cdot 7 \text {, see text. }\end{array}$} \\
\hline
\end{tabular}

blance to the corresponding enzyme from Alcaligenes eutrophus H16 (Tunail \& Schlegel, 1972) which, however, is additionally subject to allosteric inhibition by phosphoenolpyruvate. In contrast, we found the $A$. beijerinckii enzyme was unaffected by 0.5 mm-phosphoenolpyruvate although some inhibition occurred at $2 \mathrm{~mm}$.

6-Phosphogluconate dehydrogenase. The assay for this enzyme gave a steadily increasing reaction rate if 6-phosphogluconate was added last to the assay system and a faster, linear rate if NADP were the final addition. This suggested that the substrate for the observed reaction was being generated from 6-phosphogluconate as would be the case if the EntnerDoudoroff enzymes converted 6-phosphogluconate to pyruvate and glyceraldehyde 3phosphate and the latter compound served as substrate for the glyceraldehyde-3-phosphate dehydrogenase which is NADP-dependent in A. beijerinckii (Senior \& Dawes, 1971). To test this possibility the assay was performed in the presence of increasing concentrations of hydrazine, which sequesters glyceraldehyde 3-phosphate. In the presence of $82 \mathrm{~mm}$ hydrazine, which completely inhibits glyceraldehyde-3-phosphate dehydrogenase, NADP reduction was abolished. In comparable experiments with extracts of Escherichia coli or with commercial preparations of 6-phosphogluconate dehydrogenase, hydrazine did not inhibit NADP reduction, and addition of the $A$. beijerinckii extract to the $E$. coli extract did not affect the activity of the latter (Fig. 1).

Attempts were also made to assay 6-phosphogluconate dehydrogenase isotopically by measuring ${ }^{14} \mathrm{CO}_{2}$ production from 6-phospho[1-14 $\left.\mathrm{C}\right]$ gluconate in the presence of arsenite to prevent pyruvate oxidation. Controls incorporated $\left[1{ }^{14} \mathrm{C}\right]$ pyruvate to prevent the possibility of error due to ${ }^{14} \mathrm{CO}_{2}$ release from this keto acid, which is produced by Entner- 


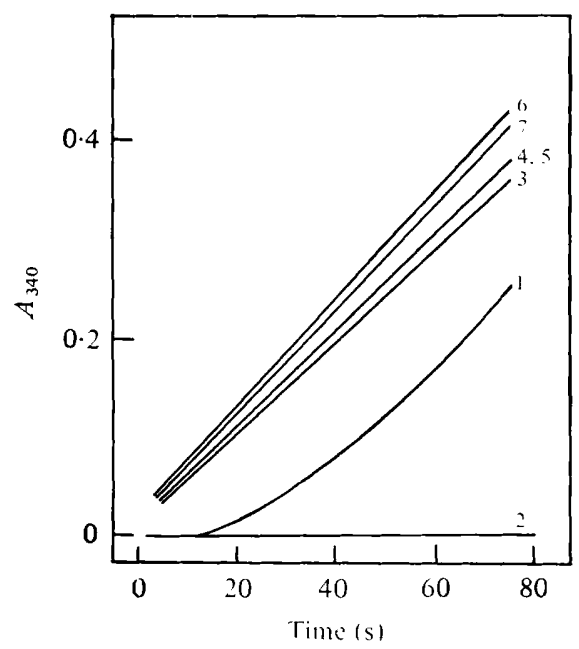

Fig. 1. Effect of hydrazine on the assay for 6-phosphogluconate dehydrogenase in $A$. beijerinckii, $E$. coli and yeast. Assays for 6-phosphogluconate dehydrogenase were carried out in the presence and absence of $82 \mathrm{mM}$-hydrazine with extracts from $A$. beijerinckii and $E$. coli, and with commercial 6-phosphogluconate dehydrogenase from yeast (Sigma; P0507): $A$. beijerinckii extract, hydrazine absent (1), present (2); E. coli extract, hydrazine absent (3), present (4); combined $A$. beijerinckii and $E$. coli extracts, hydrazine present $(5)$; yeast 6 -phosphogluconate dehydrogenase, hydrazine absent (6), present (7).

Doudoroff activity. Convincing evidence for the oxidative decarboxylation of 6-phosphogluconate could not be obtained and it was concluded that 6-phosphogluconate dehydrogenase does not play a significant role in the metabolism of $A$. beijerinckii.

Transketolase and transaldolase. In the absence of 6-phosphogluconate dehydrogenase, production of pentoses from fructose 6-phosphate and glyceraldehyde 3-phosphate by the non-oxidative reactions of the pentose cycle must be inferred and the enzymes catalysing these reactions were sought and found (Table 1). Crude extracts from carbon-limited organisms gave an optimum $\mathrm{pH}$ of 7.7 for transaldolase but because of a shortage of substrate it was not possible to ascertain the optimum $\mathrm{pH}$ for transketolase which was therefore assayed at the same $\mathrm{pH}$.

Phosphoglucose isomerase. This enzyme was present (Table 1) and displayed optimum activity between $\mathrm{pH} 7.7$ and 8.2 in triethanolamine $/ \mathrm{HCl}$ buffer.

Fructose-1,6-bisphosphate aldolase. Low activities were observed unless extracts were supplemented with either $\mathrm{Co}^{2+}, \mathrm{K}^{+}$or $\mathrm{NH}_{4}{ }^{+}$ions (Table 2). Maximum activity was observed in the presence of $\mathrm{Co}^{2+}$ which was subsequently used in all assays. Mercaptoethanol or cysteine at $1 \mathrm{~mm}$ final concentration abolished activity but $1 \mathrm{~mm}$-glutathione was without effect. The specific activities of the aldolase from carbon- and oxygen-limited A. beijerinckii are given in Table 1.

Phosphofructokinase. All efforts to detect this enzyme in A. beijerinckii extracts failed under conditions which gave satisfactory assays with $E$. coli extracts and samples of the commercial rabbit muscle enzyme.

Triosephosphate isomerase. Activity was significantly higher in extracts prepared from carbon- than from oxygen-limited organisms (Table 1).

Pyruvate dehydrogenase. The partially purified enzyme, which was free from $\beta$-ketothiolase, acetoacetyl-CoA reductase and NADH oxidase, was not inhibited by phosphoenolpyruvate (10 mM), AMP (1 mM), ATP (1 mM), acetoacetate (1 mM) or 3-hydroxybutyrate (10 mM). Acetyl-CoA showed competitive inhibition with respect to CoASH, and NADH inhibited in a non-compulsory ordered manner. The apparent $K_{m}$ for pyruvate was $0.5 \mathrm{mM}$, for NAD $0.15 \mathrm{~mm}$ and for CoASH $42.5 \mu \mathrm{M}$. This enzyme thus displays properties similar 
Table 2. Effect of cations on fructose-1,6-bisphosphate aldolase activity

$\begin{array}{lcc}\text { Cation } & \begin{array}{c}\text { Concn } \\ (\mathrm{mM})\end{array} & \begin{array}{c}\text { Specific activity } \\ \text { [nmol } \begin{array}{c}\text { NADH utilized } \text { min }^{-1} \\ \left.(\mathrm{mg} \text { protein })^{-1}\right]\end{array}\end{array} \\ \text { None } & - & 7 \\ \mathrm{Co}^{2+} & 0 \cdot 1 & 97 \\ & 1 \cdot 0 & 94 \\ \mathrm{~K}^{+} & 2 \cdot 0 & 92 \\ \mathrm{NH}_{4}^{+} & 50 \cdot 0 & 82 \\ \mathrm{~K}^{+}+\mathrm{Co}^{2+} & 50 \cdot 0 & 68 \\ & 50 \cdot 0+1 \cdot 0 & 95\end{array}$

to pyruvate dehydrogenases from other sources in being inhibited by a short-chain acylCoA ester (Erfle \& Sauer, 1969) and by NADH (Hansen \& Henning, 1966).

\section{DISCUSSION}

Results with chemostat-grown organisms confirm our previous findings with batch cultures that glucose is metabolized in $A$. beijerinckii principally via the Entner-Doudoroff pathway and also demonstrate that the oxidative pentose phosphate pathway is not of significance in this organism. The absence of phosphofructokinase precludes the operation of glycolysis. Pentoses required for nucleic acid synthesis can be synthesized from fructose 6-phosphate and glyceraldehyde 3-phosphate by the non-oxidative reactions catalysed by transketolase and transaldolase, both enzymes being present. As phosphoglucose isomerase, fructose-1,6-bisphosphate aldolase and triosephosphate isomerase are all present, fructose 6-phosphate and glyceraldehyde 3-phosphate can be produced from glucose 6-phosphate, and it seems that the main function of fructose-1,6-bisphosphate aldolase would be in pentose formation, its activity being very much lower than that of the combined EntnerDoudoroff enzymes.

Previous reports of the presence of 6-phosphogluconate dehydrogenase in Azotobacter vinelandii (Mortenson \& Wilson, 1954; Haaker \& Veeger, 1976) and A. beijerinckii (Senior \& Dawes, 1971) are probably explained as artefacts caused by the operation of the EntnerDoudoroff enzymes on 6-phosphogluconate to produce glyceraldehyde 3-phosphate, which is then oxidized by the NADP-dependent glyceraldehyde-3-phosphate dehydrogenase; a similar situation applied with $P$. aeruginosa, since Blevins et al. (1975) have shown that mutants devoid of 6-phosphogluconate dehydratase are unable to metabolize glucose. However, the situation in $A$. vinelandii was initially somewhat confused. Thus Mortenson \& Wilson (1954) reported 6-phosphogluconate oxidation by extracts and claimed that the dehydrogenase differed from others in not requiring $\mathrm{NAD}(\mathrm{P})$ as its hydrogen acceptor; subsequently they stated that all attempts to demonstrate the presence of the 6-phosphogluconase had failed (Mortenson et al., 1955). No explanation for these discrepancies was offered.

Separation of 6-phosphogluconate dehydratase from KDPG aldolase permitted identification of the dehydratase as the locus of action of the inhibitory effects of ATP and tricarboxylic acids reported by Senior \& Dawes (1971). However, these effects depended on the concentration of divalent metal ions present and the extent to which the tricarboxylic acids and ATP sequestered the available activating ions; they would not, therefore, seem to be of physiological significance and the major regulatory site for hexose phosphate metabolism is glucose-6-phosphate dehydrogenase, allosterically modulated by ATP, ADP, NAD and NADP but virtually unaffected by phosphoenolpyruvate.

While a systematic comparison of the effects of different nutrient limitations was not our prime objective, such observations as were made indicated that the levels of the in- 
vestigated enzymes of carbohydrate metabolism were higher in carbon-limited than in oxygen-limited organisms.

Poly- $\beta$-hydroxybutyrate synthesis in $A$. beijerinckii is initiated by diversion of acetyl-CoA, destined for oxidation via the tricarboxylic acid cycle, to acetoacetyl-CoA formation as a result of oxygen limitation, effected by the intracellular concentrations of free CoASH and NADH (Senior \& Dawes, 1973). In addition to this fine control, the levels of activity of NADH oxidase, isocitrate dehydrogenase and 2-oxoglutarate dehydrogenase all decreased while those of $\beta$-ketothiolase and acetoacetyl-CoA reductase increased, when an oxygen limitation was imposed; in contrast, citrate synthase and pyruvate dehydrogenase were relatively unaffected (Jackson \& Dawes, 1976). Pyruvate dehydrogenase is a multicomponent system and the complex in $A$. vinelandii has been the subject of detailed biochemical study (Bresters et al., 1975; De Abreu et al., 1977).

The demonstration of the fine control of pyruvate dehydrogenase in A. beijerinckii by NADH indicates that when an oxygen limitation is imposed the rate of acetyl-CoA formation from pyruvate will decrease until poly- $\beta$-hydroxybutyrate synthesis is initiated and the $\mathrm{NADH} / \mathrm{NAD}$ ratio restored to near its original value; at a dilution rate of $0.1 \mathrm{~h}^{-1}$ this takes almost $2 \mathrm{~h}$ (Jackson \& Dawes, 1976).

We are greatly indebted to the Agricultural Research Council for a grant-in-aid and to Mr I. D. Marriott for skilled technical assistance.

\section{REFERENCES}

Blevins, W. T., Feary, T. W. \& Phibbs, P. V., JR (1975). 6-Phosphogluconate dehydratase deficiency in pleiotropic carbohydrate-negative mutant strains of Pseudomonas aeruginosa. Journal of Bacteriology 121, 942-949.

Bray, G. A. (1960). A simple efficient liquid scintillator for counting aqueous solutions in a liquid scintillation counter. Analytical Biochemistry 1, 279-285.

Bresters, T. W., De Abreu, R. A., De Kok, A., Visser, J. \& VEeger, C. (1975). The pyruvatedehydrogenase complex from Azotobacter vinelandii. European Journal of Biochemistry 59, 335345.

De Abreu, R. A., De KoK, A. \& Veeger, C. (1977). Transformation of the 4-component pyruvate dehydrogenase complex from Azotobacter vinelandii into a 3-component complex. FEBS Letters 82, 89-92.

Erfle, J. D. \& Sauer, F. (1969). The inhibitory effects of acyl-coenzyme A esters on the pyruvate and $\alpha$-oxoglutarate dehydrogenase complex. Biochimica et biophysica acta 178, 441-452.

FaIk, P., Kornberg, H. L. \& McEvoy-Bowe, E. (1971). Isolation and properties of Escherichia coli mutants defective in 2-keto-3-deoxy-6phosphogluconate aldolase activity. FEBS Letters 19, 225-228.

HAAKer, H. \& Veeger, C. (1976). Regulation of respiration and nitrogen fixation in different types of Azotobacter vinelandii. European Journal of Biochemistry 63, 499-507.

Hansen, R. G. \& Henning, H. L. (1966). Regulation of pyruvate dehydrogenase activity in Escherichia coli K-12. Biochimica et biophysica acta 122, 355-358.

Jackson, F. A. \& Dawes, E. A. (1976). Regulation of the tricarboxylic acid cycle and poly- $\beta$-hydroxybutyrate metabolism in Azotobacter beijerinckii grown under nitrogen or oxygen limitation. Journal of General Microbiology 97, 303-312.

Meloche, H. P. \& Wood, W. A. (1966). 2-Keto-3deoxy-6-phosphogluconate. Methods in Enzymo$\log y$ 9, 51-53.

Mortenson, L. E. \& Wilson, P. W. (1954). Initial stages in the breakdown of carbohydrates by Azotobacter vinelandii. Archives of Biochemistry and Biophysics 53, 425-435.

Mortenson, L. E., Hamilton, P. B. \& Wilson, P. W. (1955). Dissimilation of 6-phosphogluconate by Azotobacter vinelandii. Biochimica et biophysica acta 16, 238-244.

Senior, P. J. \& Dawes, E. A. (1971). Poly- $\beta$ hydroxybutyrate biosynthesis and the regulation of glucose metabolism in Azotobacter beijerinckii. Biochemical Journal 125, 55-66.

Senior, P. J. \& Dawes, E. A. (1973). The regulation of poly- $\beta$-hydroxybutyrate metabolism in Azotobacter beijerinckii. Biochemical Journal 134, 225238.

Senior, P. J., Beech, G. A., Ritchie, G. A. F. \& Dawes, E. A. (1972). The role of oxygen limitation in the formation of poly- $\beta$-hydroxybutyrate during batch and continuous culture of Azotobacter beijerinckii. Biochemical Journal 128, 1193-1201.

Shaltiel, S. \& ER-Al, Z. (1973). Hydrophobic chromatography: use for purification of glycogen synthetase. Proceedings of the National Academy of Sciences of the United States of America $\mathbf{7 0}$, $778-781$.

StILl, G. G. \& WANG, C. H. (1964). Glucose catabolism in Azotobacter vinelandii. Archives of Biochemistry and Biophysics 105, 126-132.

TunaIl, N. \& Schlegel, H. G. (1972). Phosphoenolpyruvate, a new inhibitor of glucose-6phosphate dehydrogenase. Biochemical and Biophysical Research Communications 49, 1554-1560. 